\title{
Outbreak of Fusarium wilt in seedless watermelon seedlings in the Northern Territory, Australia
}

\author{
L. T. T. Tran-Nguyen • B. D. Condé • S. H. Smith • \\ L. I. Ulyatt
}

Received: 15 February 2012 / Accepted: 11 April 2012/Published online: 2 May 2012

(C) Australasian Plant Pathology Society Inc. 2012

\begin{abstract}
Watermelon Fusarium wilt caused by Fusarium oxysporum f. sp. niveum was first detected in the Northern Territory, Australia in May 2011. The disease affected seedlings and plants from three triploid seedless watermelon varieties from six locations. Pathogenicity tests were conducted and the fungus was shown to be pathogenic. This outbreak is the first report of Fusarium wilt in triploid seedless watermelons with symptoms similar to bacterial leaf blotch and typical wilt in Australia.
\end{abstract}

Keywords Fusarium wilt $\cdot$ Watermelon $\cdot$ Fusarium oxysporum f. sp. niveum

\section{Introduction}

Watermelon production in the semi-arid tropical north of the Northern Territory occurs from March to October, while production in the arid southern part of the NT occurs in the spring (September to November) and autumn (March to May). Forecast value of production for 2011-2012 is $\$ 47.8$ million from ca. 900 ha (Jean 2010). Both seedless and seeded (long melon) varieties are grown, but more than $90 \%$ of watermelons sold are seedless (S. Smith, pers. comm.). All watermelons from the NT are sold within Australia, mostly to large population centres in the eastern and southern Australian states during the cooler months when locally grown watermelon from southern Australia is not available. Modern growing systems are used to cultivate

L. T. T. Tran-Nguyen $(\bowtie) \cdot$ B. D. Condé $\cdot$ S. H. Smith

L. I. Ulyatt

Plant Industries, Department of Resources, GPO Box 3000, NT 0801, Darwin, Australia

e-mail: lucy.tran-nguyen@nt.gov.au watermelon in the NT; all crops are grown under plastic or organic mulch, watered using underground drip irrigation and fertilised with a combination of dry and soluble fertiliser.

Fusarium wilt is one of the most severe diseases of watermelon (Citrullus lanatus (Thun.) Matsum \& Nakai) and is caused by Fusarium oxysporum f. sp. niveum (Fon). This forma specialis is only pathogenic on watermelons and can be divided into four races $(0,1,2$ and 3) (Crall 1963; Elmstrom and Hopkins 1981. Netzer 1976; Netzer and Weintall 1980; Zhou et al. 2010). Two of the races have been detected in Australia (Horlock 2004). Fusarium wilt of watermelon occurs on every continent except Antarctica (Egel and Martyn 2007). The disease is one of the major yield limiting factors in production, worldwide (Zhang et al. 2005). Symptoms include damping-off, seedling wilt or general wilting during any stage of plant development (Bruton et al. 2007). The fungus can survive many years in the soil as chlamydospores and is spread by soil, plant debris, and farm machinery and on seeds (Martyn and Bruton 1989, Bruton et al. 2007). Since 2000 , there has been a significant increase in the triploid seedless watermelon industry in the USA, Europe and Australia. Prior to this, only resistant melon varieties were grown in Australia (Horlock 2004) in significant amounts. However the new triploid melon varieties appear to have little or no resistance to Fusarium wilt (Paulus et al. 1976; Bruton et al. 2007). Worldwide, it was not until Fusarium wilt became a major limiting factor before grafted watermelon seedlings were used as an alternative. Grafting watermelon seedlings onto resistant cucurbit rootstocks is common practice in many countries as a management option (Lee 1994; Lee and Oda 2003; Lopez-Galarza et al. 2004; Miguel et al. 2004; Boughalleb et al. 2007; Yetisir et al. 2007; Besri 2008; Dau et al. 2009a). In Australia, using grafted watermelon is 
becoming a more common commercial practice in Queensland, New South Wales and Western Australia (S. Smith and B. Condé, pers. comm.).

Watermelon seedlings and plants from six locations in the NT were found to express symptoms such as leaf necrosis, necrotic blotching (Fig. 1e) and seedling deaths in seedling trays, as well as, wilting and vine collapse in the field (Fig. 1a and b). Glasshouse trials in Qld revealed Fon to cause more severe wilt symptoms in seedless compared with seeded watermelons but it is not known whether leaf blotch was observed (Persley and Horlock 2003). In common with the observations of Dau et al. (2009b) in Vietnam, vascular discoloration was not observed in wilted plants in the field or in the pathogenicity tests, except for one mature field plant (Fig. 1c and d). Leaves of infected field plants and those in pathogenicity tests did not show yellow chlorosis. One-sided wilt, where only one or two branches of the vine showed wilt was common in experimental plants.
During the process of diagnosis, bacterial leaf blotch caused by Acidovorax avenae subsp. citrulli (Jones et al. 2001) and abiotic causes were eliminated. Isolations onto culture plates from necrotic areas of seedlings yielded only miscellaneous fungi including Macrophomina phaseolina. Abiotic causes were eliminated when seedlings initially responded to water then wilted again after several days. Vascular wilt disease was then investigated. The causal agent was isolated from symptomatic watermelon seedlings (Fig. 1e) by excising stem sections close to the crown of the plant surface sterilising in $70 \%$ ethanol for $1 \mathrm{~min}$, then rinsed for $1 \mathrm{~min}$ in sterile distilled water. These tissue pieces were then sliced into smaller pieces and embedded into potato dextrose agar plates supplemented with $1 \%$ lactic acid (PADL). Isolation plates were incubated at $25^{\circ} \mathrm{C}$ for $2-$ 3 days, after which Fusarium-like spores were observed. Single spore Fusarium cultures were used for all subsequent pathogenicity tests and DNA analysis.
Fig. 1 Watermelon plant growing in the field showing wilt symptoms caused by Fusarium oxysporum f. sp. niveum (a); symptomless watermelon plant (b); field sample displaying vascular colouring ( $\mathbf{c}$ - cross section, $\mathbf{d}$-longitudinal section); watermelon seedlings with Fusarium wilt and leaf blotch symptoms (e), inoculated watermelon seedling from pathogenicity tests (f). Images by B. Condé and L. Ulyatt

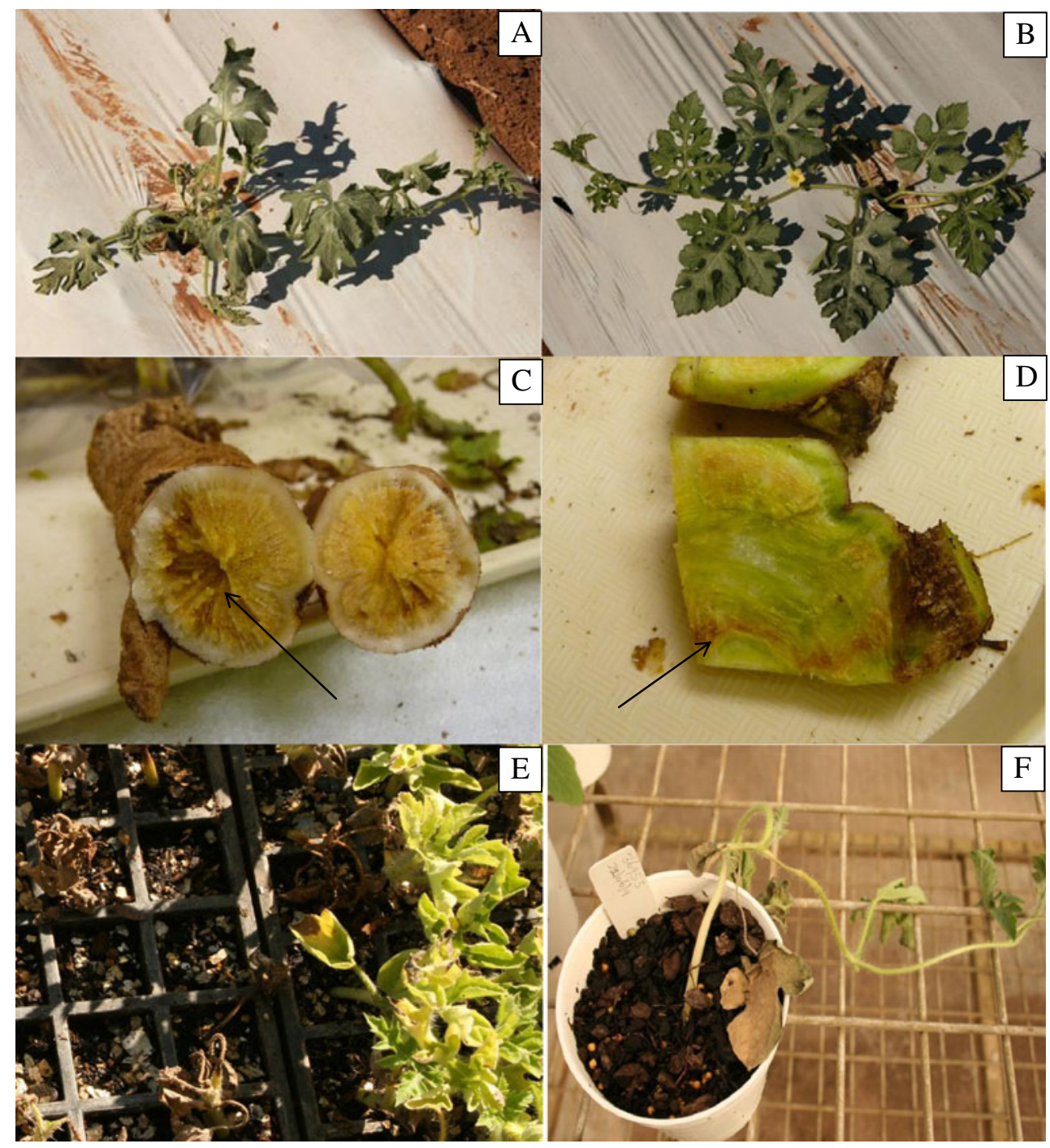


Table 1 Watermelon Fusarium isolates used in pathogenicity tests

\begin{tabular}{lcl}
\hline $\begin{array}{l}\text { Sample number } \\
\text { (NTP-Ds) }\end{array}$ & $\begin{array}{l}\text { Darwin North Australia Pathology } \\
\text { Herbarium Number (DNAP) }\end{array}$ & Organism \\
\hline 20353 & 4677 & Fusarium oxysporum f. sp. niveum \\
20353 & 4678 & Fusarium oxysporum f. sp. niveum \\
20346 & 4679 & Fusarium oxysporum f. sp. niveum \\
20346 & 4680 & Fusarium oxysporum f. sp. niveum \\
20355 & - & Fusarium oxysporum \\
20355 & 4681 & Fusarium oxysporum f. sp. niveum \\
20355 & 4682 & Fusarium oxysporum f. sp. niveum \\
\hline
\end{tabular}

Six Fon and one Fusarium oxysporum (Fo) isolates (Table 1) used in the pathogenicity tests were identified morphologically, with colonies forming microconidia in false heads on short monophialides (Burgess et al. 2008). Colonies were generally beige-pink coloured from below on PDAL. For pathogenicity testing, agar containing 6-8 day old cultures were placed in a sterile $10 \mathrm{~cm}$ diameter pots containing sterile potting mix and healthy 'Sugar Baby' watermelon seedlings. Plants were 21 to 63 days old at the time of inoculation. For each treatment, there were two replicates for each isolate including the control which consisted of a PDAL plate with no culture. This process was repeated five times until a total of ten replicates were obtained for all isolates. Inoculated seedlings were observed daily post inoculation for symptom development (Fig. 1f).

Typical wilt symptoms were observed on inoculated young seedlings after a minimum of 8 days post inoculation and up to 25 days in older seedlings (Fig. 1f). No symptoms were observed for seedlings inoculated with the $F_{O}$ isolate or the control seedlings. Fusarium oxysporum f. sp. niveum was reisolated in all symptomatic seedlings and verified using the Fon PCR specific test. Thus indicating that the causal organism isolated from watermelon was Fon and pathogenic. Fon was not isolated from any of the control plants or any of the plants inoculated with $F_{O}$.

DNA was extracted from single spore culture lawns grown on duplicate $90 \mathrm{~mm}$ PDAL plates until mycelium growth covered the plates. The Fusarium DNA was extracted using a DNeasy plant mini kit (Qiagen, Australia) following the manufacturer's instructions. PCR primers ITS5 and ITS4 (White et al. 1990) were used to amplify 650 bp segment of the ribosomal RNA (rRNA) - internal transcribed spacer (ITS) region. Specific Fon PCR primers, Fon-1 and Fon-2, based upon a RAPD Fon marker from a Taiwan isolate Fon H0103 (Lin et al. 2010), were used to amplify a 174 bp product. Specific Fo PCR primers, FnS-1 and FnS-2, were also used to amplify a 320 bp product (Lin et al. 2010). PCR reactions were conducted in a $25 \mu \mathrm{L}$ mixture containing $1 \mathrm{X}$ ImmoMix Red with $3 \mathrm{mM} \mathrm{MgCl}_{2}$ (Bioline, Australia) and $0.2 \mu \mathrm{M}$ of each primer and 5-10 ng of DNA template. The ITS PCR conditions used were initial enzyme activation of $95^{\circ} \mathrm{C}$ for $10 \mathrm{~min}$; followed by 35 cycles of denaturing at $95^{\circ} \mathrm{C}$ for $1 \mathrm{~min}$, annealing at $56^{\circ} \mathrm{C}$ for $1 \mathrm{~min}$, extension at $72^{\circ} \mathrm{C}$ for $1 \mathrm{~min}$ and final extension of $72^{\circ} \mathrm{C}$ for $10 \mathrm{~min}$. Fon/Fo specific PCR conditions were initial enzyme activation of $95^{\circ} \mathrm{C}$ for $10 \mathrm{~min}$; followed by 30 cycles of denaturing at $94^{\circ} \mathrm{C}$ for $30 \mathrm{~s}$, annealing at $60^{\circ} \mathrm{C}$ for $30 \mathrm{~s}$, extension at $72^{\circ} \mathrm{C}$ for $1 \mathrm{~min}$ and final extension of $72^{\circ} \mathrm{C}$ for $10 \mathrm{~min}$.

PCR products from Fon, Fo and ITS PCR tests were purified (Fig. 2) using the QIAquick PCR purification kit (Qiagen, Australia) according to the manufacturer's instructions. The products were sequenced using the Big Dye Terminator Mix (Australian Genome Research Facility, Brisbane). Bioinformatic analyses were conducted using
Fig. 2 Agarose gel electrophoresis of PCR products amplified from specific Fon, Fo and ITS PCR tests. M. $1 \mathrm{~Kb}$ Plus marker, 1-7. Fon isolates, 8. Fusarium oxysporum f. sp. tracheiphilum, 9. Sterile distilled water

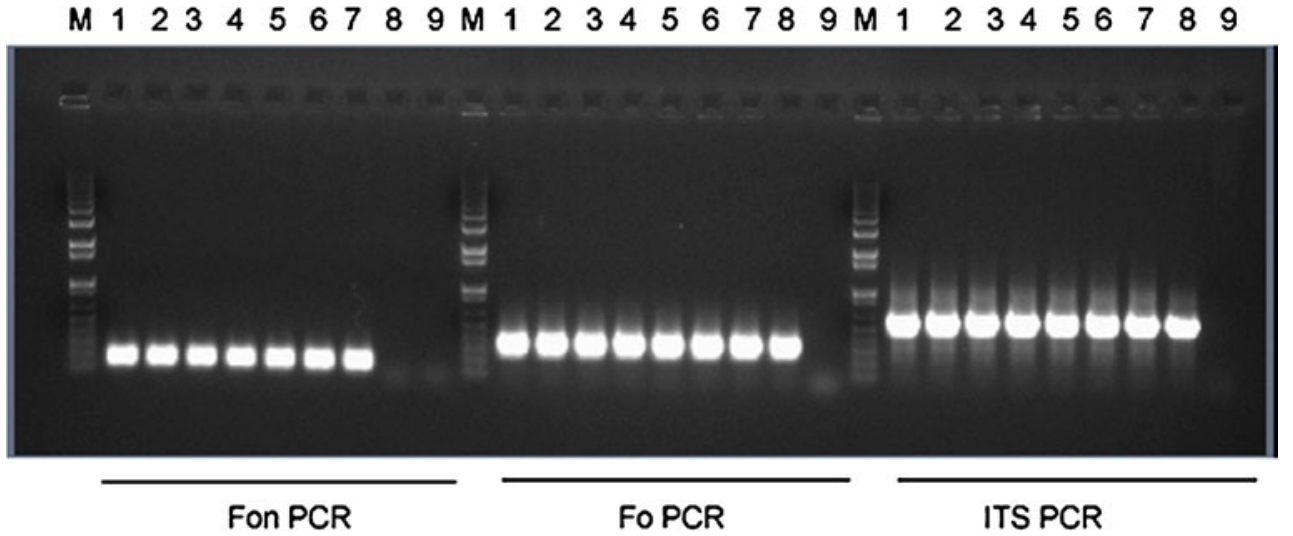


Geneious Pro 5.4.6. software (Drummond et al. 2010). The nucleotide sequence of DNAP 4677 was deposited into GenBank and assigned the accession number JQ446080.

All isolates except $F o$ were positive in the Fon specific PCR test (Fig. 2). While all isolates were positive in the $F_{O}$ and ITS PCR tests. Bioinformatics analyses confirmed that isolates which were positive in the Fon specific test were $100 \%$ similar to the Fon H0103 Taiwan isolate (GenBank Accession Number EU60350). The ITS sequences were able to characterise to species level only and identified as Fusarium oxysporum. The PCR tests did not differentiate between the Fon races (Lin et al. 2010; Zhou et al. 2010). Pure isolates of these Fon cultures have been deposited in the Darwin North Australia Pathology Herbarium and assigned numbers listed in Table 1.

Further investigations will be conducted to identify the Fon race infecting NT watermelons. Control measures such as grafting on resistant rootstocks will be investigated. To our knowledge, this is the first report of a major outbreak of Fusarium wilt of seedless watermelon seedlings with symptoms similar to bacterial leaf blotch and typical wilt in Australia.

Acknowledgments Authors would like to thank Louisa Cowie for technical assistance.

\section{References}

Besri M (2008) Cucurbits grafting as alternative to methyl bromide for cucurbits production in Morocco. Proceedings of the 14th International Research Conference on Methyl Bromide Alternatives and Emissions Reduction, Orlando, pp 60-61

Boughalleb N, Tarchoun N, El Mbarki A, El MM (2007) Resistance evaluation of nine cucurbit rootstocks and grafted watermelon (Citrullus lanatus L.) varieties against Fusarium wilt and Fusarium crown and root rot. Journal of Plant Sciences 2:102-107

Bruton BD, Fish WW, Zhou XG, Everts KL, Roberts PD (2007) Fusarium wilt in seedless watermelons. In: Kelley WT, (ed) Proceeding 2007 Southeast Regional Vegetable Conference 2007: Savannah, Georgia pp 93-98

Burgess LW, Knight TE, Tesoriero L, Phan HT (2008) Diagnostic manual for plant diseases in Vietnam. ACIAR Monograph No 129. Australian Centre for International Agricultural Research, Canberra

Crall JM (1963) Physiologic specialization in Fusarium oxysporum f. sp. niveum. Phytopathology 53:873

Dau VT, Dang NV, Nguyen DH, Pham LT, Le TTM, Phan HT, Burgess L (2009a) A simplified technique for grafting watermelon onto resistant cucurbit rootstocks for control of Fusarium wilt of watermelon in Nghe An Province, Vietnam. Aust Plant Dis Notes 4:114-116

Dau VT, Burgess LW, Pham LT, Phan HT, Nguyen HD, Le TV, Nguyen DH (2009b) First report of Fusarium wilt of watermelon in Vietnam. Aust Plant Dis Notes 4:1-3
Drummond AJ, Ashton B, Buxton S, Cheung M, Cooper A, Duran C, Field M, Heled J, Kearse M, Markowitz S, Moir R, Stones-Havas S, Sturrock S, Thierer T, Wilson A (2010) Geneious v5.5, Available from http://www.geneious.com

Egel DS, Martyn RD (2007) Fusarium wilt of watermelon and other cucurbits. Plant Health Instruct. doi:10.1094/PHI-I-2007-0122-01

Elmstrom GW, Hopkins DL (1981) Resistance of watermelon cultivars to Fusarium wilt. Plant Dis 65:825-827

Horlock C (2004) Fusarium wilt of melons (Watermelon, rockmelon and honeydew). DPI \& F Note. pFile No: H0235

Jean M (2010) Northern Territory rural industries and fisheries economic outlook 2010. Primary Industries Group, Northern Territory Government, Darwin

Jones JB, Gitaitis RD, Schaad NW (2001) Gram-negative bacteria. Acidovorax and Xylophilus. In: Schaad NW, Jones JB, Chun W (eds) Laboratory guide for identification of plant pathogenic bacteria, 3rd edn. The American Phytopathological Society, USA, pp $121-138$

Lee JM (1994) Cultivation of grafted vegetables. Current status, grafting methods and benefits. Hortscience 29:235-239

Lee JM, Oda M (2003) Grafting of herbaceous vegetable and ornamental crops. Hortic Rev 28:61-125

Lin Y-H, Chen K-S, Chang J-Y, Wan Y-L, Hsu C-C, Huang J-W, Chang P-FL (2010) Development of the molecular methods for rapid detection and differentiation of Fusarium oxysporum and F. oxysporum f.sp. niveum in Taiwan. New Biotechnol 24(4):409-418

Lopez-Galarza SA, San Bautista DM, Perez DM, Miguel A, Baixauli C, Pascual B, Maroto JV, Guardiola JL (2004) Effect of grafting and cytokinin induced fruit setting on color and sugar content traits in glasshouse-grown triploid watermelon. J Hortic Sci Biotechnol 79(6):971-976

Martyn RD, Bruton BD (1989) An initial survey of the United States for races of Fusarium oxysporum f. sp. niveum. HortScience. 24 (2):696-698

Miguel A, Maroto JV, San Bautista A, Baixauli C, Cebolla V, Pascual B, Lopez S, Guardiola JL (2004) The grafting of triploid watermelon is an advantageous alternative to soil fumigation by methyl bromide for control of Fusarium wilt. Sci Hortic 103:9-17

Netzer D (1976) Physiological races and soil population levels of Fusarium wilt of watermelons. Phytoparasitica 4:131-136

Netzer D, Weintall C (1980) Inheritance of resistance in watermelon to race 1 of F. oxysporum f.sp. niveum. Plant Dis 64:853-854

Paulus AO, Harvey OA, Nelson J, Shibuya, F. (1976) Fusariumresistant watermelon cultivars. Calif Agric 5-6

Persley D and Horlock C (2003) Management of virus diseases and bacterial leaf blotch of melons. Horticulture Australia Limited VX99037 final report

White TJ, Bruns T, Lee SB, Taylor JW (1990) Amplification and direct sequencing of fungal ribosomal DNA genes for phylogenetics. In: Innis MA, Gelfand DH, Sninsky JJ, White TJ (eds) PCR protocols: a guide to methods and applications. Academic Press, New York, pp 315-322

Yetisir H, Kurt S, Sari N, Tok FM (2007) Rootstock potential of Turkish Lagenaria siceraria germplasm for watermelon: plant growth, graft compatibility, and resistance to Fusarium. Turk J Agric For 31:381-388

Zhang Z, Zhang J, Wang Y, Zheng X (2005) Molecular detection of $F$. oxysporum f.sp. niveum and Mycosphaerella melonis in infected plant tissues and soil. FEMS Microbiol Lett 249:39-47

Zhou XG, Everts K, Bruton BD (2010) Race 3, a new and highly virulent race of $F$. oxysporum f.sp. niveum causing Fusarium wilt in watermelon. Phytopathology 94(1):92-98 